\title{
Atete: A Multi-functional Deity of Oromo Women with Particular Emphasis on Human Rights and Conflict Resolution Management
}

\author{
TEMAM HAJIADEM HUSSEIN \\ Department of History and Heritage Management, College of Social Sciences \\ and Humanities, Haramaya University, Ethiopia.
}

\begin{abstract}
The roles of women in any society were the focuses of many researchers. Some of them concluded women role in any society was minimal. But this is not true for Oromo women. It is for this reason that this paper briefly discusses the roles of Ateetee Oromo women deity system in socio-cultural lives of Oromo nation. The research explores how the Oromo women used this deity system to defend their rights and solve arising conflict in the society peacefully. It also outlines special cultural and ritual objects women used to promote peace, human rights, social justice; to overcome natural disasters through prayers and to strike cosmos balance between the creator and creatures. Since there is a dearth of written material which deals with Ateetee, the researcher therefore depend on some oral traditions and anthropological investigation carried out for many years. Based on the investigation and analysis of these sources, the writer concluded that the Oromo society developed a highly sophisticated Ateetee system to safeguard women rights and protect the rights of the weak group at least from the time of Gadaa advent. Ever since, they also used it for solving arising conflict in Oromo society peacefully. Moreover, contrary to many writers the focuses of Ateetee system were not only confined to fertility matter but also focused on many issues that affect all Oromo groups including male as my investigation established.
\end{abstract}

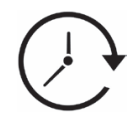

Article History

Received: 19 November 2018 Accepted: 3 June 2019

\section{Keywords}

Ateetee;

Conflict Resolution Method; Human Rights;

Ritual;

Siinqee.

CONTACT Temam Hajiadem Hussein $\$$ thajiadem @gmail.com 9 Department of History and Heritage Management, College of Social Sciences and Humanities, Haramaya University, Ethiopia.

\section{(c) (i)}

(C) 2019 The Author(s). Published by Enviro Research Publishers.

This is an Open Access article licensed under a Creative Commons license: Attribution 4.0 International (CC-BY).

Doi: http://dx.doi.org/10.12944/CRJSSH.2.1.03 


\section{Introduction}

The Oromo are one of the ancient people and the largest single ethno-nation in Ethiopia (Legesse, 1973; Hassen, 1990, 1996; Woliye, 2004) and Horn of Africa, comprising around $40 \%$ of the Ethiopian people (Tareke, 1991; Baxter, 1994; Woliye, 2004). They speak Afaan Oromoo which belongs to the Eastern lower Cushitic. Cushitic family is one of the six sub- division of Afro-Asiatic super-family. Moreover, Afaan Oromoo is third widely spoken languages in Africa (Muudee, 1995; Hordofa, 2001; Woliye, 2004). With the exception of northern part of Ethiopia the Oromo people occupied the most fertile regions in the south, southeast, east, west and central parts of Ethiopia including where the capital Addis Ababa is found and what the country exports mainly also come from Oromo land.

The Oromo were initially agriculturalist pastoralists and governed by the Gadaa system. Gadaa is the set of institutions around which the Oromo organized their political, social and cultural lives (Cerulli, 1922; Legesse, 1973; Melba, 1988). It was also a system of rituals of worship and a judicial system with legal provisions for the prevention of crimes. It had provisions against adultery, theft, insult, murder, slander, corruption, etc. It had also elaborate series of provisions by which the victims would be compensated for damages inflicted upon them. It had a body of rules governing conduct in society, of men towards women, juniors towards seniors and children toward adults (HajiAdem, 2017). Many scholars tried to define Gadaa system, however, the best often quoted definition was that of Asmarom Legesse's definition. Asmarom Legesse, an Eritrean anthropologist had said that Gadaa has three interrelated meanings: it is the grade during which a class of people assumes politico-ritual leadership, a period of eight years during which elected officials take power from the previous ones, and the institution of Oromo society (Legesse, 1973). It was probably due to this complex nature of the Gadaa that Asmarom Legesse called it "one of the most astonishing and instructive turns the evolution of human society has taken" (Legesse, 1973). It is also for this importance that the eleventh UNSCO conference on intangible world cultural heritage held on 30 November 2016 in Addis Ababa inscribed the Gadaa system as one of world's intangible cultural heritage of humanity.
In Oromo society there are also two systems by which the women played a significant role in conflict resolution and protection of their rights. These are Ateetee and Siinqee (sometimes also written as siiqee) systems. Unlike men the Oromo women lack comparable age-based social organization like the Gadaa system (Kelly, 1992; Legesse, 1973). However, there are socially recognized ways of categorizing the role and status of women in Oromo society. The Gadaa system provides the women with another system in which the Oromo women participate in the socio-cultural activities that protect their rights. Furthermore, these systems also helped the women to mobilize themselves for various causes among which that harm their group identity. These two systems, Ateetee and Siinqee are clearly indicative of the place women had in the religious, social and cultural philosophy of the Oromo people (Woliye, 2004) and these systems of women function hand in hand with the Gadaa system as one of its built-in mechanism of checks and balances (Megerssa, 1993; Kumsa, 1997; HajiAadaam, 2011).

The incorporation of the Oromo land into Emperor Menelik's Empire during late 19th century, and the expansion of Islam and Christianity disintegrated the overall socio-political structure of the Oromo (Baxter, 1978; Hassen, 1990; Jalta, 1996). These two events greatly weakened both the Gadaa System, the hallmark of the Oromo democracy (Lewis, 1965; Hinant, 1978; Legesse, 1973; Bernardi, 1985; Hassen, 1990; Jalata, 1996) and the various socio-cultural practices including Ateetee ritual. Unfortunately, the ruining of the Gadaa System created a widespread socio-political imbalance, one of which could be the wearing away of socio-political leverage granted women in the Gadaa System (Woliye, 2005).

The Oromo Gadaa system, muudaa voyages to land of Abba Muudaa was forbidden during Menelik period. Both, Ateetee rituals and women's Ateetee artifacts were considered backward and forbidden. With the coming to power of new government led by the Ethiopian People's Revolutionary Democratic Front (EPRDF) in 1991 the Oromo land became one of the nine federal regional governments. The new federal structure seeking to redress the imparity of the past introduced a policy intended to secure the rights of the many ethnic and religious groups, both 
recognizing the diversity and seeking to enhance equality within the diversity. Accordingly, Afaan Oromoo became a working language in Oromo region, Oromia. The new structure also allowed the right to promote one's culture and to profess his/ her religion freely. Hence, the articulation of national identities, the reproduction of ethnic symbols and the demarcation of ethnic boundaries become more visible (Østebø, nd).

One of the Oromo women socio-cultural and ritual practices forbidden during old regimes but after 1991 development got the attention is the Ateetee ritual practices. Before 1991 Ethiopia Historiography did not give significant attention to Oromo people one of the single largest nation let alone to the history of Oromo women. The conquered people history was distorted and largely ignored. Few studies that were carried out have been mainly characterized by demeaning, misrepresentations, distortions and even portraying the people as having no culture and past history (Giorgis, nd; Tamrat, 1972; Ullendorff, 1965; Gellner, 1983). Alem Desta (2008) who wrote on Ethiopian women history in 2008 had concluded that the Ethiopian women role in socio-cultural milieu was almost non existence. Furthermore, she concluded that Ethiopian women had no rights even at family and clan levels before 1991. This is not true for Oromo women.

The central objective of this article has been to discuss the Ateetee deity system function in Oromo community in general and the defense of Human rights and Conflict resolution methods in particular. The Oromo women from ancient times through Ateetee system had played major roles in defending women rights, contributing to conflict management mechanisms and growth of democratic principles. I will, moreover, discuss the material objects the women employed in the rituals; the types and processes of Ateetee rituals performed to defend women rights. The discussion will similarly focus on siinqee and qanafaa concepts which are related to Ateetee system in managing conflicts. It is also intended that this work will contribute to the debate on human rights and conflicts resolution methods. However, my intention is not to forward Oromia as a source of the birth of human rights but rather to move beyond one-sided approaches to the study of human rights principles, conflict management mechanisms and social justice. Instead, I will argue in favor of an inclusive approach, which sees other areas as a point of departure for the birth and growth of human rights and conflict resolution methodology.

\section{The Methodology}

When I was teaching history in high schools (Western Wallagga, Arsi and Shewa) and higher institutions (Adama and Haramaya) my students from various areas of Oromia brought a fascinating thing about Oromo women rights which broadened my previous knowledge about Ateetee ritual and its implication for development of human rights, conflict resolution management and social justice. It is these ideas which attracted me to dig out further and do more research on the role of women in Oromo society. Nevertheless, there is the dearth of written material on Ateetee system and cultural history. Those few scholars who discussed about it focused on either one or two aspects of Ateetee system. They lacked holistic approaches. So the shortcomings necessitated me to go further and investigate the problem using various methods and procedures of data gathering techniques. Some of the methods of data gathering technique employed here are conducting interviews with Oral informants including both male and female group who had deep knowledge of Ateetee rituals in both Arsiland and Shewa regions. I also used observation method when Ateetee participants performed their rituals for rain seeking ceremonies at Sirka in Arsi in 2013 as well as when Ateetee attendants sat for negotiation with elders under qiltu tree at Arsi Nagelle in Eastern Shewa in 2014. I also grew in Oromo society where some Oromo ancient practices continued unabated including Ateetee rituals in spite of hostility from the previous oppressive regimes and religious leaders. This also broadened my Ateetee Knowledge. Moreover, I also collected different Ateetee hymns composed by Oromo women that came down from their mothers, grandmothers and great grandmothers through oral transmission. The researcher employed various research procedures like recording data obtained from informants using audio recording and also taking field notes. Later these data organized under different themes. The researcher cross-checked them systematically with written fragmentary secondary sources found in various libraries in order to obtain a reliable and valid research finding. The researcher finally employed 
critical analysis technique in order to interpret and write the final work.

The researcher fundamentally followed ethnographic approach to study the socio-cultural history and anthropological inquiry of Ateetee Oromo women. It is also qualitative in nature and design. The study is concerned with Oromo women ontology of how they organized reality in their minds and expressed it in their Ateetee ritual ceremony. As Darnton correctly argued Socio-cultural history should focus on such type of ritual practices (Darnton, 1984, 1). Hence, ethnographic accounts of Ateetee Oromo women socio-cultural and ritual practices are constitute the central part of the paper. The article also intended to demonstrate the importance of integrating Oromo women concepts of human rights, conflict management system and social justice as an important part of the development of International instruments of human rights and conflict management systems. It also shows that the concepts of human rights and conflict management system are not relative rather it is universal concepts emerged in various parts of the world including Oromia and Ethiopia in ancient period.

\section{Results and Discussion What is Ateetee and Why Do the Womenfolk Perform it?}

Under this section, I will discuss the definition of Ateetee and ayyaana. I will also explain the motives Ateetee ritual ceremonies held in Oromo society with major emphasis on the issues related to women rights and managing conflict. Lastly, siinqee institution will be discussed briefly in relation to Oromo women wayyooma, high honor and sacredness and their importance in resolving socio-cultural evils.

It is very difficult to define the term Ateetee. According to Kuwee Kumsa(1997), Ateetee is a female deity. Ateetee is also a spirit (ayyaana). Based on these concepts and information gathered from informants, I define Ateetee as a special spiritual power given to Oromo married women by Waaqa (God). Ateetee helps mother to deliver a new born baby safely without any difficulties. Due to this reason, Ateetee is also known by its honored title ateetiyyoo or aayyoolee (my Ateetee or my mother). As mentioned above, Ateetee is a married woman ayyaana. It is also not easy to translate the word ayyaana into English since it has different meaning according to different contexts. One of the nearest definition of ayyaana is a spirit through which the women and religious leaders, Qaallu communicate with Waaqa, God (Knutsson, 1967; Bartels, 1983). The second meaning of ayyaana could be the name of seven day of a week or 27 days in a month of Oromo lunar calendar called Dhahaa Oromo (Legessa, 2000; HajiAadaam, 2011). The other meaning of ayyaana is the commemoration of a special holiday whether it is a public or religious holiday. The last nomenclature is a new phenomenon in Oromo history. So the nearest meaning of ayyaana in English is the first and the second according to its context. There are many ayyaana in Oromo cosmogony, some of which are ayyaana of man, animal, soil, tree and so on (Daaniyaa, 2006). ${ }^{1}$

Ateetee ritual ceremonies were performed by Oromo women for various motives. Some of these motives why the rituals could be held include to mitigate recurring drought, overcome crop failure, alleviate epidemic diseases or defend Oromo lands if it attacked by the enemy. It could also be invoked for animal fertility or to express happiness when good events occurred in the Oromo community. ${ }^{2}$ However, the main motives most of the times Ateetee ayyaana ritual organized by women is to safeguard and protect their rights from infringement by husband or any male offenders and to solve arising conflicts peacefully (Megerssa, 1993; Kumsa, 1997; Woliye, 2004). As most of us knew the Oromo nation was one of the first people who developed an egalitarian system of democracy. Even though, Eurocentric view believes that democracy start in Greece at Athens around $508 \mathrm{BC}(\mathrm{J}$. Peradotto and Sullivan (eds), 1984), the Oromo institution of Ateetee and Gadaa system show that there is also another source that contributed to the growth of democracy, the principles of human rights and conflict resolving mechanisms as the following discussion will be demonstrating.

1Oral Informants: Haji Adam Haji Hussein and Obbo Adem Hussein interviewed at Adelle on 19 July 2015 ${ }^{2}$ My personal knowledge 
In Greece democracy there is no major roles for women in contrast to Oromo women who played a major role in their society. The Oromo women participated in Gadaa power transfer ceremony. The newly elected Abba Gadaa could not be blessed with out the presence of Qalluu and women (Legesse, 1973, Megerssa, 1993). It is the task of women during blessing ceremony that the elected officials should pass under siinqee (I will discuss about it later) that they held in inverted V. This is due to a belief that the women had a religious authority. In all major daily socio-cultural activities women had a significant role and were even given a special highly respected status called Wayyuu (Kumsa, 1997; Wako, 1998; Woliye, 2004; Østebø, 2009). When they spoke the community listened to and appreciated it. It was also believed that women were weak (liminal) parts of humanity and thus wield a special religious power where they draw an enormous moral and ritual authority (Kumsa, 1993; Kelly, 1993). These characteristics feature of Oromo women helped them to play a major role in solving community problems. One of the roles they played in Oromo society is settling disputes among clans and sub-clans. If by chance conflict emerged among members of Oromo clans, the Oromo women could stop it through a process called hanfalaa hikkachuu ( from Oromo, hanfalaa is a belt made of leather by which women tie their waist while hikkachu is taking off it (Woliye, 2004; Østebø, 2009; HajiAadaam, 2011).

Hanfalaa hikkachuu is a process of performing a symbolic gesture where clothes are taken off to show a complete surrender to God. Once this action was symbolically performed by Oromo women everybody that involved in the conflict will stop it automatically (Woliye, 2004; Østebø, 2009). The role of conflict resolution management undertaken independently by women was initially envisioned in Oromo socio-cultural code of conduct and further separately formulated in Ateetee system. We did not see this type of respect and influence in ancient Athenian democracy as well as even in the modern western democracy until the end of WWII (Peradotto and Sullivan (eds), New York, 1984). Peradotto and Sullivan discussed that both Women and Slaves were seen as the natural and biological inferiors of the patriarchal male citizen with in Greek culture. Furthermore, Anne Mclintock (1995) discussed that women and slaves were similarly distinguished from free men by their social subordination and their imagined otherness. They also shared exclusion from participation in political life and were viewed as morally deficient and potentially dangerous. Until the modern period, Europeans were even burning millions of women at the stake as witches (Kumsa, 1997, 114).

Contrary to this, Oromo say "kabajni ilma namaa dubartii dha", the honor of human beings is due to womenfolk. Women could use this influence and power bestowed on them by Oromo society in conflict resolution management and also when their rights and children rights violated and even when the natural environment affected (Megerssa, 1993; Kumsa, 1997; Wako, 1998). ${ }^{3}$ As mentioned at the beginning of this work, the Oromo Gadaa system is one of the most democratic institution dominated predominantly by male while the Ateetee system and Siinqee on the other hand dominated by women. Even though, we do not know when Ateetee and Siinqee institution started, many Oromo people believe that it is as old as Gadaa system. Thus, the history of Ateetee institution is as old as both Gadaa system and Qaallu institution. It is linked highly to the Qaallu institution whose history traced back to the fell of the first Qaallu from sky in immemorial period (Bartles, 1983; Daaniya, 2006). Likewise, some Oromo clans also believed that the Ateetee ayyaana also fell down from the sky in that immemorial period (Daaniya, 2006; HajiAadaam, 2011). So we can infer from these hypotheses that Ateetee ayyaana is highly related with Oromo general cosmology, mythology and with the advent of the first Qaallu in Oromo history.

Let us now briefly discuss what Siinqee is and stands for as it is a very important tool in conflict resolution management and defending women's rights. Siinqee is thin long beautiful stick up to one's length or more which is given on marriage day by a mother to her married girl. So it should be kept as very precious object with respect. The Oromo people believed that the first Qaalluu was

${ }^{3}$ Oral Informants: Obbo Adem Hussein and Adde Makko Haji Qassim interviewed at Adelle on 19 July 2015 
given a siinqee (ritual stick) to take home for his wife (Woliye, 2004). It comes from harooressaa tree and has huge meaning in Oromo nation (Megerssa, 1993; .Kumsa, 1997). Once the woman carry this object in her hand and travel through Oromo lands the people ought to give her a special reverence. Likewise, if she offended by her husband and grabbed it by her right hand and went to Oromo elders, she was given a due regard and listened to attentively. When some people saw woman carrying it and travelled through out the village, they would murmur to each other by saying that balaa maltu bu'e, what calamities happened to us? This shows that siinqee represent a big weapon for women for fighting injustice and oppression. Moreover, siinqee stick symbolizes special cultural object that have endowed with feature of respectfulness, peacefulness and protection of women rights which enabled women to solve conflicts emerged in their locality easily (which will be discussed later in detail).

\section{Where and When is Ateetee Ayyaana Celebrated?} In this section, I will enumerate some of the ritual objects employed in various Ateetee rituals in different parts of Oromo lands. Moreover, the Oromo calendar known as dhahaa Oromoo is important in socio-cultural life of Oromo because the Oromo daily activities highly related to prayers and ritual performances. Hence, it is incumbent on every Oromo to know on which day a particular ayyaana fell that has auspicious omen for their daily activities. This is also the concern of the section. Briefly the places at and occasion on which Ateetee ritual ceremonies will be held by women will be discussed.

The places where the Ateetee ceremonies could be hold varies according to the motives Ateetee ritual ceremonies will be celebrated. In the same manner, Ateetee ritual objects used in the celebration of the ayyaana could also slightly differ. Some of these cultural objects employed in the Ateetee ritual celebrations slightly differ in some places but its overall function is the same and hence the readers should understand in that manner. Few of the cultural objects commonly used in most Ateetee ayyaana ritual ceremonies in Oromo land are callee (small beads mainly produced in Middle east), siinqee, okolee and kiila (butter container), guchuuma and ciiccoo (milk container), gaadi (leather to tie two legs of a cow during milking), coqorsaa (special grass which spreads broadly over the wide area), caccuu (beads), ulmaayi leaves (it have good aromatic), various ritual clothes (wandabboo, qoloo, xibbiqqo, qomee, bonkoo, gufta, sabbataa, naxalaa) and others. Food items like marqaa, qincee, hangoo (porridge made from black barley), urgooftu (made from roasted barley) and qixxaa, bread of barley also important for the ritual ceremonies. Other cultural objects like ciiccoo or qorii (porridge vessel), gilgil or gimmiccaa (callee container), various drinks ( dadhii, booka, mijuu or buquri), gingilchaa, buqqee, coffee beans, barley, butter, various perfumes (aarrittii, hixaana, qumbii), at some places cereals like nug seed were also needed for the ceremonies. At some places particularly in Arsi land heexoo, kasaa erbee, mukaa qayyaa and other objects used. Depending on the resource of a person who celebrates, Ateetee ayyaana as well as the motives why it is celebrated black sheep which had white color on its head or bull could also be needed for ceremonial sacrifice in Ateetee ayyaana celebration process. These all cultural materials and ritual objects which are highly related to fertility and reconciliation mechanisms are considered as a femininity tools in Oromo culture. ${ }^{4}$

Moreover, due to above factors the place where Ateetee ayyaana and the days on which it could be celebrated vary. The day on which the Ateetee ritual celebrated could be calculated by ayyaantu or elders. Not all elders knew how this is calculated because the calculation involves knowing precisely the position of the stars and their movement, hence related to Oromo calendar calculation. The Oromo lunar calendar have 27 days which all have their own ayyaana and the remaining three days calculated by looking at the position and movement of stars in the sky (Legesse, 1973; HajiAadaam, 2011). In Oromo calendar each day had its own ayyaana and some ayyaana are believed to be not having good omen. For example, the ayyaana name of one day is related to a donkey; hence the Oromo considered this day has not had good omen. Knowing and calculating on which day a good ayyaana fell is important because each day has its own special ayyaana with different connotation.

${ }^{4}$ Oral Informants: Adde Tayiba Safi and Adde Zara Karrayu interviewed at Sirka on 17 November 2014. 
Some are very good ayyaana, others are good while some have bad omen, hence, this categorization is necessary to the people to know on which day these various types of ayyaana will fell.

The Oromo people in order to identify on which day important ceremonies could be held including Ateetee ceremonies, had used to calculate looking at the appearance of the new moon and important stars for a thousand of years. This led as to dhahaa Oromoo or faana buutuu Oromoo (Oromo calendar). ${ }^{5}$ By doing this they correctly calculated on which day a good ayyaana would fell. The first day start from the night of the appearance of a new moon. It has its own ayyaana name. For instance, the first day's ayyaana is called Hinikkaa. Hinikkaa is the first name of ayyaana for the new day of a month. Oromo month has about 29 or 30 days. However, apart from the first 27 days the last three days or two days has no ayyaana. As we discussed at the beginning of this work ayyaana has many meaning. According to this context ayyaana means the name given to each new day of a month. The $28^{\text {th }}, 29^{\text {th }}$ or $30^{\text {th }}$ day took its name/ayyaana from the $1^{\text {st }}$ or $2^{\text {nd }}$ or $3^{\text {rd }}$ days of outgoing month. But this needs special calculation which only done by a few knowledgeable people. So every new month's last two or three days will take the name/ayyaana of $1^{\text {st }}, 2^{\text {nd }}$ or $3^{\text {rd }}$ of outgoing month which will change from month to month. The next month the $28^{\text {th }}, 29^{\text {th }}$ or $30^{\text {th }}$ days could took probably the $4^{\text {th }}, 5^{\text {th }}$ or $6^{\text {th }}$ day's ayyaana of previous month. It is this difficulties that necessitated calculation by special people, ayyaantu or elders. Sometimes people could forget the name of ayyaana of the day and when this happens the ayyaantu go out of his home in the night and look upwards to the sky to see the setting of these stars known in Oromo as lamii, buusaa, sorsa, alqaajima, arba guddaa, hulqaa(wallaa) and basaa, position of the moon or at the daybreak to see bakkalcha (Venus) and other stars which could help to calculate the ayyaana. ${ }^{6}$ Likewise, the day or ayyaana for Ateetee ceremony that has good omen will be established. Probably it was for this fact that Asmarom Legesse (1973) had written that the Oromo calendar with the Chinese, Indian and Maya is the best permutation calendar ever recorded in human history.
From the above name or ayyaana of days of the month, I can postulate that the Oromo originally divided one month into twenty-seven ayyaana not into four weeks. To support this idea let see names of the day in different parts of Oromia. To begin, the two Oromo moieties Borana and Barentu have different names for the days of the week. Nowadays the names of the week we use in Oromia are the following: Wixata, Kibxata, Roobi, Kamisa, Jimaata, Sanbataa and Dilbataa. The name Roobii, Kamisa, Jimaata and Sanbata have similarities with Arab names of the days whose meaning connote four, five for the first two names while the last name connote seven respectively. Arabs started the first day of the week with Sunday that is Alahad, its meaning is one. The only dissimilar name of the week with the Arabs is Wixata, Kibxata and Dilbataa. For Itu and Humbana Oromo all name of the week is similar with Arabs. Wixata and Kibxata were common name in Arsi and Borana areas, while in west Oromia for Wixata and Kibxata they used the name of Dafno and Facaasa while in central Oromia they used Hojja duree and Lammaffoo. From this discussion, I like to say that this difference in naming the days of the week probably stemmed from originally all Oromo clans used twenty-seven ayyaana names for a month not naming days of the week. It seems to me that the nomenclature of the week was a later development. Moreover, it seems to me that initially it was more Ayyaana naming preferred nomenclature for days of a month in Oromo religious, social and cultural performances and festivities to the names of the weeks mentioned above.

The most preferred days on which Ateetee ayyaana ceremonies could be hold throughout Oromo lands are Tuesday, Thursday and Saturday (Daaniya, 2006). If these days had a bad ayyaana name, the day could shift to those that had a good omen. The length of the days for which Ateetee ceremony is held varies from the factors why the ceremony is celebrated. The average days of celebration were from 1-3 day/s. The other seasons in which Ateetee celebrated are after Irrecha festivity in the autumn (end of rainy season) and also after Tullu irrecha festivity in spring (the beginning of afrasa/badhessa rainy season). ${ }^{7}$ It could also be celebrated by

5Oral Informants: Haji Adam Haji Hussein and Obbo Adem Hussein interviewed at Adelle on 19 July 2015. ${ }^{6} \mathrm{Ibid}$. Asmarom, 1973 added Bakkalcha in the first category instead of Sorsa. 
mothers when their children did a bravery act. Or any mother who faced with a major problem could celebrate Ateetee ayyaana providing that the day had a good ayyaana. It was also celebrated in the month of November and January in some places. Again when Oromo nation faced with great calamities, the womenfolk could organize the Ateetee ritual ceremony when they deemed it is necessary to do so.

Types and Processes of Ateetee Ayyaana Ritual Celebration (Kabaja/Facaafata)

Before discussing the above theme, it is very necessary to say a few passing remarks about Oromo religion. The first and original religion of Oromo was Waaqeffannaa, the belief in Waaqa (the Supreme Being, God). The name Waaqeffannaa comes from Waaqa, the black God, the creator of all things. Black color, to the Oromo, represents future, prospers, hopes and is considered to be a symbol of holiness and divinity. The definition of Waaqa itself is difficult. For instance, Knutson who studied the Oromo religion defined Waaqa as the vault of the sky or the sky itself or linked with the sky (Knutson, 1967). While Mohammed Hassen defined Waaqa as both the sky god and the sky itself, manifesting the dual nature of the two moieties within the nation who controlled the fertility, peace and life-giving rains (Hassen, 1990). Huntingford also defined Waaqa as the creator and lord of the earth who had the power doing good and evil (Huntingford, 1975). The Oromo Waaqa has no representation with an image. According to the Oromo belief, Waaqa talks to his people through the Qaalluu. The Qaalluu are the ritual leaders of the Oromo. The Qaalluu are people who are anointed by God to manifest his power and work (Trimingham, 1965). Nowadays the majority of the Oromo are the followers of Christianity and Islam. As in the rest of Africa, religious and cultural syncretism of blending both Islamic and Christian elements with those from traditional religion (Woliye, 2004; Lewis, 1980) is also evident among the Oromo. The best example of cultural syncretism is the celebration of Ateetee rituals by both Islam and Christianity followers which is the main discussion point of this paper.
I have discussed in the previous section that the Ateetee ayyaana ritual celebration is performed in slightly different forms due to the various motives it is celebrated. Here, I will discuss how the process of Ateetee ayyaana is accomplished with particularly emphasis on women role in conflict solving resolution. Moreover, other positive deeds of Oromo women in relation to harmonizing relationships between uumee (God) and uumaa (creatures) so as to keep the cosmos in balance will be discussed. For the sake of our discussion, I divided Ateetee ritual celebration into three major groupings. These are: Ateetee ritual celebration held to defend women rights, Ateetee ritual celebration held to alleviate drought and seek more rain and Ateetee celebration held to express good wishes and joyful occasion. Therefore in this section, I will demonstrate how Ateetee ritual ceremony was more than a fertility rite and had to do a lot with many issues which are inclusive of all Oromo groups including male. Furthermore, I will also argue that some of the previous works had focused on single aspects of Ateetee function, the case in point was P. Baxter (1979). who focused only on fertility issue from Arsi Oromo perspective. But here, I will argue in this section based on my field observation, intensive interviews and my personal experience that Ateetee function is broader and focused on many aspects of not only women matter but also all Oromo groups including male issue.

\section{Ateetee Ritual Celebration Held to Defend Women Rights}

Before discussing the main function of Ateetee rituals, it is very important first to define what Ritual is. Like Ateetee and ayyaana, Ritual is also another difficult word to define; however, for the sake of simplicity I adopted this definition of rituals. According to Thomas Hylland Eriksen $(2010,223)$ Ritual is the social aspect of religion. It is also the social processes which give a concrete expression to the system of religious notions. On the other hand Terence Turner (1977: 54) emphasizes that there exists an 'iconic relationship' between the structure of rituals and that of the social relations which they mediate. 'Ritual', he explains, 'as a symbolic model of social order that also attempts to be an effective

${ }^{7}$ Oral Informants: Haji Adam Haji Hussein and Obbo Adem Hussein interviewed at Adelle on 19 July 2015 
means of regulating that order, is grounded upon the same fundamental structural and dynamic principles as society itself'. From this point of view, ritual serves as a symbolic instrument which not only represents, but also constructs, social reality. These theoretical insights hold true for the Oromo case (Aneesa Kassam, 1999; Smith, 1989: 50).

\section{Ateetee Ritual Celebration Held to Protect and Defend the Rights of Pregnant Women, Newly delivered Women and Mothers}

Oromo woman from the time of a delivery of a new baby to at least up to two months or at most up to six months put a special object called qanafaa on her forehead. Qanafaa is highly valued object in Oromo society. It is made from the harder bark of a tree. When any Oromo woman who ties it along her forehead passed through the neighborhood, the local people took for granted that the woman in question had give birth recently and hence everybody in the village should give her a special protection and fulfills her needs. The Oromo women are given a special care even more during pregnancy and ulmaa (after birth postpartum rest period). This could be mount, special sitting or material objects. ${ }^{8}$

Nevertheless, a few ill-tempered individuals might not give a special care for pregnant woman or to a woman who wears qanafaa. They might insult or demean or batter her when she was in such a status. Moreover, some wicked husbands also might do the same to his pregnant or newly delivered wife. Even in some cases some bad boy might insult or look in contempt up on his mother. Any person who hurt the wayyuu woman that wears qanafaa physically and psychologically is considered as immoral person. He broke the overall Oromo ethical values and religious principle (Safuu cabsuu). The Oromo community reacted harshly to such person. A special corrective program will be initiated. Failure to observe the ritual prohibition, provokes the village women into agitation and protest (Kumsa, 1997; Woliye. 2004; HajiAadaam, 2011)
The process of bringing the offender to Oromo special corrective tribune could be commenced by woman in question or by any woman who saw or heard this act. Either of them could initiate invoking Ateetee ayyaana to intervene and help them quickly. During this moment, the women folk hurriedly grab their siinqee in their right hand raising and directing upwards to Waaqa burst out of homes in raised voices uproar like a lion in invoking their mother ateetiyyoo. And in the left hand they could carry lush fresh grasses (Megerssa, 1993; Woliye, 2004). Simultaneously, they begin the weeddisu/singing of Ateetee ayyaana accompanying by declaration of ililllliiiiiiiiii (ululation). These actions signaled the beginning of Ateetee ritual process in the earnest. The process of organizing and holding any Ateetee ayyaana ritual ceremonies by the women is called Ateetee kabaajatuu or bulfachuu or facaafatuu.

They might pronounce this weeddu / Ateetee hymn at this moment ${ }^{9}$ which symbolized a kind of ultimatum declared by Ateetee attendants to offender to pay compensation (falu, maru) on time.

\begin{tabular}{|c|c|}
\hline Afaan Oromoo & English translation \\
\hline Intala aayyaa dhageette & $\begin{array}{l}\text { Did the womenfolk } \\
\text { hear the news? }\end{array}$ \\
\hline $\begin{array}{l}\text { Dhalti tiyya dhaananii } \\
\text { oduun si geettee }\end{array}$ & $\begin{array}{l}\text { He humiliated my } \\
\text { fertile, did not the news } \\
\text { reach you? }\end{array}$ \\
\hline $\begin{array}{l}\text { Uumaa na dabse } \\
\text { oduun si geettee }\end{array}$ & $\begin{array}{l}\text { He spoiled the nature, } \\
\text { did you hear the news? }\end{array}$ \\
\hline Qanafaa na cabse & Did you hear the news? \\
\hline oduun si geettee & $\begin{array}{l}\text { He destroyed the } \\
\text { qanafaa. }\end{array}$ \\
\hline
\end{tabular}

Once they heard this hymn/song, the neighboring women in the village one by one join the offended woman and march together towards the nearby caffee, grassy area or qilxuu, considered as female tree or sycamore tree for excommunication of the offender. The Oromo elders who are monitoring

\footnotetext{
${ }^{8}$ Oral Informants: Adde Tayiba Safi and Adde Zara Karrayu interviewed at Sirka on 17 November 2014. ${ }^{9}$ Common Ateetee hymns in most parts of Oromia ${ }^{10}$ Oral Informants: Adde Tayiba Safi and Adde Zara Karrayu interviewed at Sirka on 17 November 2014; My personal observation
} 
the march of the womenfolk towards ceremonial place would inquire politely the Ateetee participants why they came out en masse. At this moment, the elders seize fresh lush grass in their right hands as sign of seeking peace and alangee (whip made from hippopotamus skin) in their left hand as sign of peaceful arbitration, approach the Ateetee participants by saying "dhiltee dhinaa" (special spiritual opening talk during ritual ceremony, seeking apology for direful eye contact). The women would respond unanimously by saying "hobbayaa" (no matter and we accepted your saying) or hoofkolaa (be relieved). After the positive signal from the women the elders enter into negotiation with the saddeetan group or the saddeettan hanfalaa (council of senior mothers) who led the complaints of Ateetee attendants (Kumsa, 1997; Woliye, 2004).

After a lengthy discussion on the issue by two groups, lastly they come out with a resolution that declares the offender to compensate the offended woman. The guilty person might pay fine in property and also slaughter a sacrificial animal as a good gesture. He also made to cook and feed the party at the feast as a gesture of reconciliation (Megerssa, 1993). If he brought big animal like bull to be slaughtered as a sacrificial animal, the womenfolk would not take it quickly. They would say "marga afaan keene" (literally, let it graze pasture more). But if he insisted, they might take it or changed to sheep. This proves that the whole reconciliation and conflict resolution methods intention is not to harm the offender but rather it is to bring about a permanent reconciliation through fair compensation whereby nobody harmed beyond his/her capacity.

In case if the accuser refused to compensate the offender, the Ateetee participants curse him and tore down his home. The male elders also declared him of guilty of violating the Oromo moral principles (safuu \& wayyomaa) and ostracized him pending he pay full compensation. Until he does that, he will not participate in marital and burial ceremonies with the people and etc. He will also not be elected in any Gadaa office. If his offensive was severe, he could be banished (Megerssa, 1993).

In rare case if a child insults his mother the Ateetee ritual process could be initiated like above but the hymn/song will significantly differ. ${ }^{10}$
Afaan Oromoo

English translation

Kiila sii sifeesse

Da'ee si geessise

Abboo salphadhu

Saree hanqadhu

I gave you a special care By giving birth \& caring, I make you a responsible person

Now you humiliated yourself

Your humiliation should be even less than that of a dog

Like the above reconciliation process, the boy would also compensate his mother according to his capacity and join his family peacefully as before.

In short, the Oromo society had developed very encouraging and corrective social sanction by which all of their population abides. These laws and social sanctions made the Oromo society to live a happy and peaceful life where nobody harmed beyond his/her capacity. It is a society build up on adab (mutual interdependence; recognizing the rights of each other; giving precedence to elders, mothers, and pregnant women, having mercy to children, domestic animals and even to natural environment) and safuu (unbroken ethical and moral rule). There are similar indigenous conflict resolution methods in Africa like (Jir mediation of Tiv people in Nigeria, Guurti assembly in Somaliland, Mato Oput of Acholi and Ubuntu in South Africa (Francis, 2008)) but what made the Ateetee system again more unique from these systems is that it is dominated by female while the above mentioned Africans methods of conflict resolution are dominated by male.

\section{Ateetee Ritual Ceremony Held for Sick Children and Childless Women}

The ways Ateetee ritual celebration for sick children and childless women performed are significantly differ from Ateetee ritual celebration held for women or mother whose rights violated by any offenders. The difference is that the ritual ceremony held for childless women and sick children is confined to one's home with careful planning. When the day of a ritual ceremony arrived the woman who engaged in the preparation of the ceremony brought out her callee and caccuu from gilgil (a container made from grass). These items represented fertility and reconciliation with God. Once the mother who 
prepared Ateetee ceremony for sick child immerse her callee three times in refined butter and then wore over her forehead and neck, the participant women expressed their joy by saying illiilliillicha (ululation) three times. ${ }^{11}$

They performed many blessings for sick boy and specifically the mother gave the sick boy ulmaayi leaves by saying- ${ }^{12}$

\section{Afaan Oromoo}

English translation

Adda gootaa baasi

Make his forehead like that of brave man

Addi kee adda

leencaa haa ta'u Make his forehead like that of a lion

Addi kee biiftuu ta'e addunyatti haa ifu Let your forehead shines like the sun everywhere

Also for girls she did in the same manner except the mother now offered her sick girl coqorsaa grass instead of ulmaayi leaves by saying- ${ }^{13}$

\section{Afaan Oromoo}

Horii lubbuu dheeradhu

Garaan kee taadhii

haa ta'u

Bultii gaarii argadhu

Ateetee warra kee

bulfadhu

\section{English translation}

Be more fertile and live long May give birth on time on regular base Have good livelihood with your future husband Hold your family's Ateetee regularly

The process of Ateetee ceremony performed for a woman deprived of child is slightly different from the one performed for a sick child. The motive and the type of prayers to Waaqa and Ateetee ayyaana were also vary from the former. However, the materials and some acts performed are the same. In Oromo nation callee has a special place, for this reason if a mother died she bequeathed it to her eldest man's wife because it is believed that callee should not move out of mother's house. ${ }^{14}$ It is for this fact that if a male baby born the women say ululation five times and for girl they say three times respectively. When a mother of the family died, Ateetee objects were given to her eldest man's wife. The man and his wife who bequeathed Ateetee objects and other cultural costumes feel proud more than other sons and daughters of deceased mother. On the contrary, a mother who did not bear a baby boy feels unhappy because she does not have a person who bequeathed her Ateetee objects. It is for this reason that the daily ritual prayers of Oromo are focused on fertility, peace and rain (Hassen, 1990; Ayyalew, 2008).

\section{Ateetee Ritual Celebration Performed to Alleviate Drought and Seek More Rain}

The Oromo women like the larger parts of Oromo society if various problems affected the Oromo nation, they would not keep silent. The Oromo Waaqa who believed to be very merciful with big stomach (gurraacha garaa garbaa) will offer from his limitless bounty if asked honestly by surrendering one's self to him. The Oromo believe that the womenfolk and children are weak in the sight of Waaqa and when they kneel down to him, the merciful Waaqa will respond to their prayers hurriedly than to male population. This belief would encourage the Oromo women when calamities struck their community to organize the Ateetee ayyaana ritual rite to pray to Waaqa to give them more rain.

Let us now discuss the role of Oromo women in organizing Ateetee rituals and how they invoked Ateetee ayyaana and Waaqa when drought affected their community. The process of organizing the ritual could be initiated by senior women and even by male. With the communal approval of the ceremony, the next stage will be the beginning of preparation of the ceremony with the women in that locality. The womenfolk like other Ateetee ritual ceremonies wore their traditional Ateetee ritual costumes. These also brought out other objects that show the femininity. They set out in small group singing Ateetee ritual songs while carrying siinqee and coqorsaa in their hands for ceremony early in the morning. In most places in Oromo lands the womenfolk moved to

\footnotetext{
${ }^{11}$ Oral Informants: Adde Zara Aman and Adde Ganame Jiru interviewed at Hasasa on 5 October 2000.

${ }^{12}$ Oral Informants: Adde Duretti Badhaso and Dharo Kabiro interviewed at Nagelle on 23 November 2005.

${ }^{13} \mathrm{lbid}$

${ }^{14} \mathrm{lbid}$
} 
river side for ritual ceremony before the day break. On their way the Ateetee participants sung many Ateetee hymns/songs which related to prayers seeking rain like the followings- ${ }^{15}$

\section{Afaan Oromoo}

Siinqee kiyya lootii

qabadhee

Gooftaa kiyya mootii

kadhadhee

Roobaaf jedhee mana

bahee

Kiilaan bahee sitti

dheesse Rabbiyyoo

\section{English translation}

I took up my beautiful

long siinqee

I prayed to my lord God

For the sake of rain we

came out

Oh my God, We came

out with hope to get rain.

As soon as the Ateetee participants reach the ceremonial place of a river side, they immerse coqorsaa grass or other grasses which they brought out with the qarru (muddy water that pushed to side of a river by wind pressure) and then they touch it with their foreheads. This is a symbolic expression of taking the oath of sisterhood before God. In the same manner, they also placed their siinqee in the water. This is also a symbolic expression of drinking of water and hope of having more rain.

Once the symbolic drinking of water by siinqee was performed, the women could stay near river side or move their ritual ceremony to nearby caffee or qilxu tree. Here, what they first do was to hoist their siinqee at the center of the ritual ceremony whereby they continued their ritual rites like praying and singing many Ateetee hymns, eating and drinking what they brought out with them. They also slaughtered a sheep. To show their complete surrender to Waaqa as sign of humility, they also perform hanfalaa hikkachuu. They believed that Waaqa is holy and loves truth so if the womenfolk humbly surrendered to him, He will listen to their prayers. They will pronounce during that moment the following Ateetee hymn (HajiAadaam, 2011).

\section{Afaan Oromoo}

Afoofna ilillaa afoofnaa ilillaa
Waliif dhiifamaa afoo Waaqa jirraa

Let forgive each other we are before God

Subsequent to the forgiveness ceremony, the women considered themselves as pure before Waaqa who now will listen to His devotees. The rain seeking ceremony will continue like this for most part of a day.

\section{Ateetee Ritual Celebration Held to Express Good Wish and Joyous Occasions}

The Oromo women when important events that brought a great joy to their community took place they have some mechanisms by which they would express the joyous occasion. One of these mechanisms could be holding a joyous Ateetee ritual ceremony. The womenfolk could also organize Ateetee ritual ceremony when they sow their field in order to express hope and wish of good harvests. They did the same for their cattle so as to become fattier and give more milk. They also performed the Ateetee rituals as a sign of hope, excitement and promises of positive happenings during a transition from a rainy season to bright sunny season. Furthermore, they could also organize it for their family member who successfully hunted wild animals and returned with trophy or when their family member returned back from successful military expedition.

In this section, I will discuss some of the above mentioned Ateetee rituals in detail. As I mentioned above any Oromo family could organizes Ateetee ritual ceremony let say to seek for the well-being of its cattle. In the most Oromo households there was a tradition that every family should have a special cow that treated differently from other; such a cow is called an Ateetee cow (Waaqeffanaa, 2003). ${ }^{16}$ A woman who sought to organize Ateetee ritual ceremony for a well-being of her (family's) cattle ought to start to store milk and butter that come from Ateetee cow into a special container for ceremony. She should not give its butter or milk to anybody. Early in the morning of the ceremony her husband summons male neighbors to come and drink stored milk. Up on enjoying the drink, the men bless the family and the cattle. Later on, the women do the same. During this occasion the women can sing the following Ateetee hymn which glorifies the cattle, ${ }^{17}$

\footnotetext{
${ }^{15}$ Oral Informants: Adde Tayiba Safi and Adde Zara Karrayu interviewed at Sirka on 17 November 2014; My personal observation
} 


$\begin{array}{ll}\text { Afaan Oromoo } & \text { English translation } \\ \begin{array}{l}\text { Saani gabbataan kun } \\ \text { kan Ateeteeti } \\ \text { Ganni cirrii haa ta'u }\end{array} & \begin{array}{l}\text { This fatty cow belong to } \\ \text { Ateetee } \\ \text { May the horde be filled } \\ \text { with pregnant ones } \\ \text { Rimaan haphee haa ta'u }\end{array} \\ \begin{array}{l}\text { May the implant be } \\ \text { attached to wombs } \\ \text { successful } \\ \text { Mofkalee haa bobba'u }\end{array} & \begin{array}{l}\text { May cattle protected } \\ \text { and go to pasture } \\ \text { peaceful }\end{array}\end{array}$

On that ceremonial day a new kraal for cattle would be constructed and decorated with leaves of different aromatic herbs such as abbayyi, ulmaayi, urgeessaa. Inside the fence, the wet and straight stem of the tree of birbrisaa or sorooroo or ejersa or kormoomsa would be erected under which the libation rituals were held. The family also made the cattle to pass under the above trunk of trees made in the form of inverted V, which believed to have symbolized powerfulness and strength.

Ateetee good wishing ceremonies were also hold for sown seeds in order to seek the health growth of crops and good harvest. This type of Ateetee ayyaana ritual celebration is called gindii hiikaa/ Ateetee midhaanii. Particularly in Wallagga region in the month of August it celebrated colorfully (Waaqeffanna, 2003; Daaniya, 2006). They also spill out the ritual milk (mijuu) over the plowed and sown soil. This special ceremony is called dhibaafachu (libation). In Shewa the Oromo women also celebrated Ateetee ayyaana ritual during the transition from a rainy and murky summer season to bright period of autumn when crops grow luxuriantly to the satisfaction of onlookers. To observe the joyful moment the Shewan Oromo women in conjunction with masqal, Orthodox religious festival celebrate Ateetee ayyaana cheerfully singing many Ateetee hymns/songs. ${ }^{18}$ The Oromo mother also celebrated
Ateetee success ceremonies for individual who do good deeds. For instance, if one of her son successfully carried out hunting expedition and returned with a trophy, her mother could organize a victory Ateetee ceremony for him.

It is important to underscore that the above mentioned Ateetee ritual processes and practices were continued in spite of Menelik conquest of Oromo land in the nineteenth-century and also opposition from both Muslim and Christian leaders. However, the ceremony during the Shewan occupation and rule organized haphazardly and lost some of its vigor. There were also cases when the Oromo women defy the subjugation and oppression of the Shewan rule by organizing Ateetee ritual ceremony as attested by Birruu and Fato (cited in Kumsa, 1997). E. Cerulli who was in Oromo land in 1920s was extremely surprised that both the Islamized and Christianized Oromo were practicing the traditional religious practices including Ateetee rituals (Cerulli, 1922). Moreover, P. W. Baxter who was in Arsi in 1960s also observed how the Arsi Oromo women organized Ateetee ritual ceremony in their neighborhood and prayed for well-being to Waaqa (Baxter, 1979). In the same manner, Holcomb who did a research among the Oromo in 1970s reaffirmed that the Oromo women resisted the missionaries' intrusion into Oromo cultural activities by organizing sisterhood gatherings which made the missionaries to leave that area Holcomb and Sisai, 1990). Some of my informants from both Shewa and Arsi regions also confirmed that during Haile Selassie and Derg period when major crises struck their society, the Oromo women reacted by organizing Ateetee ritual ceremonies to overcome it. ${ }^{19}$ These all historical anecdotes discussed here affirmed that in spite of its decline in its influences, the Oromo women had organized Ateetee ritual ceremonies for various functions until recently.

\footnotetext{
${ }^{16}$ Oral Informants: Adde Zara Aman and Adde Ganame Jiru interviewed at Hasasa on 5 October 2000.

${ }^{17}$ Common Ateetee hymns in most parts of Oromia

${ }^{18}$ Oral Informants: Adde Zara Aman and Adde Duretti Badhaso interviewed at Hasasa and Nagelle on 5 October 2000 and 23 November 2000 respectively.

${ }^{19}$ Oral Informants: Adde Zara Aman and Adde Duretti Badhaso interviewed at Hasasa and Nagelle on 5 October 2000 and 23 November 2000 respectively.
} 


\section{Conclusion}

This work discussed and elaborated numerous Ateetee rituals, various socio-cultural ceremonies and social acts which organized and managed by Oromo women. It also showed that Oromo women through Ateetee system struggled and organized into a collective solidarity movement against rights violation and oppression by wicked male individuals to defend their rights since the advent of Gadaa system. In this article, the complex Ateetee rituals which were demonstrated had played a major role in Oromo society by solving conflicts through peaceful methodology. Hence, it contributed positively for the existence of a just and orderly society. I also argued that the notion of human rights principles and democracy were not only originated in Europe but also in Oromo land (Oromia) since the advent of Gadaa system. As our discussion indicated Oromo nation had developed and employed these concepts for many years. Hence, efforts to strengthen human rights and conflict resolution mechanisms should therefore be done with great geographical and cultural sensitivity.

Furthermore, the Ateetee ceremonies focused not only on fertility issue as some writers tried to show us, but rather it also focused on male issues, mitigation of natural calamities and protection of environment. Unlike Feminist quests for gender equality in terms of jobs and political positions which sometimes be viewed as being too individualistic and self-centered and as a luxury (Steady, 2006), the Ateetee ayyaana system and its functions on the other hand are not limited to gender issue but it is rather socio-centric and holistic. Oromo Ateetee rituals transcends individualism and tends to involve women as a group in struggles against oppression of all kinds based on political, social and cultural domination. It is more holistic and humanistic and has a greater potential for social transformation.

\section{Acknowledgment}

The author grateful to Oromo informants in Arsi and Shewa regions for their great contribution in providing invaluable oral information as well as my mother, Adde Makko Haji Qasim who taught me the Oromo culture and History since my childhood.

\section{Graph \& Table}

The author did not employ both Graph \& Table in this work since the study did not call for it.

\section{Declaration of Conflict of Interest}

The study was carried out by the author himself with out any help from any organization

\section{References}

1. Ayalew, Kanno (trans). An Ancient People Great African Nation, The Oromo as recounted by Martial de Salvaic. Finfinne: Bole Printing Press. 2008.

2. Bartels, Lambert. Oromo Religion. Myths and Rites of the Western Oromo of Ethiopia: An Attempt to Understand. Berlin: Dietrich Reimer Verlag. 1983.

3. Baxter, P.T.W. Atete in a highland Arssi neighborhood. In Northeast African Studies, 1979;1(2):1- 22. East Lansing: Michigan State University.

4. The Creation \& Constitution of Oromo nationality. In K. Fukui \& J. Markakis (eds.) Ethnicity \& Conflict in the Horn of Africa. London: Ohio University. 1979.

5. Cerulli, Enrico. "The Folk-Literature of the [Oromo] of Southern Abyssinia." In
Harvard African studies 3. Varia Africana 1994;3:9-228. Cambridge/MA

6. Daaniyaa. Waldaa Aadaa fi Duudhaa Oromoo, Finfinnee: Bole Printing Press. 2006.

7. Darnton, R. The Great Cat Massacre and other Episodes in French Cultural History. Paris: Flammarion.1984

8. Debsu, N. Dejene. "Gender and culture in Southern Ethiopia: An Ethnographic Analysis of Guji-Oromo Women's Customary Rights. African Study Monographs, 2009;30(1):15-36, March 2009.

9. Desta, Alem. Candace: Invincible women of Ethiopia. Amsterdam Eriksen, Thomas Hylland. 2010. Small Places, Large Issues: An Introduction to Social and Cultural Anthropology. London: Pluto Press. 2008.

10. Francis, J. David. Peace and conflict in Africa. 
London, Zed Books. 2008.

11. Gellner, Ernest. Nations and Nationalism. Ithaca and Oxford, Cornell University press and Blackwell. 1983.

12. Giorgis, Asme, N. D. Ya [Oromo] Tarik. Addis Ababa

13. HajiAadaam, Tamaam. Atete Sirna Addunyaarratti addaa tan mirga Dubartoota Oromoo eegduu fi eegsiftu. Dirree Dawaa, Khalaf Printing Press. 2011.

14. Hajiadem, Temam. "The Transformation of Anajina From A Religious Shrine to a Centre of Ethno-Nationalist Resistance, 2017;1881-1991." Ph.D. History Dissertation, UNISA.

15. Hassen, Mohammed. The Oromo of Ethiopia A History. 1990;1570-1860. Cambridge: Cambridge University Press

16. Holcomb, Bonnie and Sisai Ibssa. The Invention of Ethiopia: The Making of a Dependent Colonial State in Northeast Africa. New Jersey: The Red Sea Press Inc. 1990.

17. Hordofa, K. "Linguistic relationship between Oromo, Sidama, Kambata, Hadiya and Gedeo." In Wiirtuu, Journal of Oromo Language Standardization, 2001;6:164-173. New Jersey: The Red Sea Press Inc.

18. Huntingford, G.W.B. The Galla of Ethiopia: The Kingdom of Kafa and Janjero. London: Lowe and Brydon. 1975.

19. Kassam, Aneesa. "Ritual and Classification: A Study of the Booran Oromo Terminal Sacred Grade Rites of Passage." In Bulletin of the School of Oriental and African Studies. University of London, 1999;Vol.62,No.3 . Cambridge: Cambridge University Press

20. Kelly, Anna. "From Gada to Islam: the Moral authority of gender relations among the Pastoral Orma of Kenya." PhD Thesis, London 1992.

21. Knutson, K. E. Authority and Change: The Study of the Kallu Institution among the Macha [Oromo] of Ethiopia. Göteborg: Etnografiska Museet 1967.

22. Kumsa, Kuwee, "The Siiqqee Institution of Oromo Women." In Journal of Oromo Studies. Vol.4,No.1\&2. July 1997. Lawrenceville, $\mathrm{NJ}$ : Red Sea Press

23. Legesse, Asmarom. Gadaa: Three Approaches to the study of African Societies.
New York. 2006.

24. Oromo Democracy: An Indigenous African Political System. Lawrenceville, NJ: The Red Sea Press. 2000.

25. Lewis, I.M. "The Western Somali Liberation Front (WSLF) and the Legacy of Sheikh Hussein of Bale." In J. Tubiana, (ed.). Modern Ethiopia: From the Accession of Menelik II to the Protest. Addis Ababa: Rotterdam, Balkema. 1980.

26. Megerssa, Gemetchu "Knowledge, Identity and the Colonizing Structure: The Case of the Oromo in East and North East Africa." Ph.D. Thesis submitted to the Department of Anthropology, University of London, School of Oriental and African Studies. 1993.

27. Melba, Gadaa. Oromia: An Introduction. Khartoum. 1988

28. Mclintock, Anne. Imperial Leather: Race, Gender and Sexuality in the Colonial Context. New York: Albany Press. 1995.

29. Muudee, Hamid. Hamid Muudees Oromo Dictionary. Vol. I. Atlanta : Sagalee Oromoo Publishing. 1995.

30. Østebø, Marit Tolo, "Wayyuu-Women's Respect and Rights among the Arsi-Oromo." In Proceedings of the 16th International Conference of Ethiopian Studies, Svein Ege, Harald Aspen, Birhanu Teferra and Shiferaw Bekele (ed,) Trondheim. 2009.

31. Peradotto, J. and Sullivan (eds). Women in the Ancient World: The Arethusa Papers. New York: Albany Press. 1984.

32. Steady, Filomina Chioma. Women and Collective Action in Africa: Development, Democratization, and Empowerment, with Special Focus on Sierra Leone. New York: Palgrave Macmillan. 2006.

33. Smith, B. K. Reflections on Resemblance, Ritual and Religion. Oxford: Oxford University Press.1989.

34. Tamrat, Taddesse, Church and state in Ethiopia, 1270-1527. Oxford: Clarendon Press.1972.

35. Tareke, Gebru. Ethiopia: Power and Protest. Cambridge, Cambridge University Press. 1991.

36. Turner, Terence. "Transformation, hierarchy and transcendence: a reformulation of Van Gennep's model of the structure of rites de 
passage." In Sally F. Moore and Barbara G. Myerhoff (ed.) Secular Ritual. Amsterdam: Van Gorcum. 1977.

37. Tuso, Hamdesa. "The Role of Women in Conflict Resolution: Perspectives from an Indigenous System." A Leadership Journal: Women in Leadership-Sharing the Vision 2, no. 2. 1998.

38. Tuso, Hamdesa and Maureen P. Flaherty. Creating the Third Force: Indigenous Processes of Peacemaking. Peace and Conflict Studies. Lanham, MD: Lexington Books. 2016.
39. Ullendorff, Edward. The Ethiopians: An Introduction to Country and People. London: Oxford University Press.1965.

40. Waaqeffanna. Jildii IV, LK, 1. Finfinne: Bole Printing Press. 2003.

41. Wako, Dubo. Guji Social Conventions \& Laws of Society Rehearsed At 22nd Bokko Assembly. Addis Ababa: Berhanena Selam Printing Press. 1998.

44. Woliye, Jeylan Hussein. "A Cultural Representation of Women in the Oromo Society." In African Study Monographs, 2004; 25(3):103-147 